\title{
City Branding in Pekalongan, Central Java
}

\author{
R. Siti Rukayah a, Ardiyan Adhi Wibowo ${ }^{\text {b }}$, Sri Hartuti Wahyuningruma ${ }^{\text {a }}$ \\ a Architecture Department, Engineering Faculty, Diponegoro University \\ ${ }^{b}$ Architecture Department,Qur'anic Science University, \\ Wonosobo, Central Java, Indonesia \\ tututrsiti@yahoo.com
}

\begin{abstract}
There are many cities in Indonesia categorized as batik-industrial cities. Postal road that connects cities along the northern coast of Java Island passes right through Pekalongan. Through historical and naturalistic approach, this road is the promotional media for local citizens to display their industrial products, making it a shopping window. The image of Pekalongan as an industrial city is obtained naturally from the participation of its people. Pekalongan is globally professional city that has sustained its image since $1800 \mathrm{~s}$. The continuation of the research is to compare Pekalongan to another city that has successfully implemented the concept and become an advanced industrial city.
\end{abstract}

Keywords: Pekalongan; Batik; image; city

eISSN: 2398-4295 @ 2016. The Authors. Published for AMER ABRA by e-International Publishing House, Ltd., UK.. This is an open access article under the CC BY-NC-ND license (http://creativecommons.org/licenses/ by-nc-nd/4.0/). Peer-review under responsibility of AMER (Association of Malaysian EnvironmentBehaviour Researchers), ABRA (Association of Behavioural Researchers on Asians) and cE-Bs (Centre for Environment-Behaviour Studies), Faculty of Architecture, Planning \& Surveying, Universiti Teknologi MARA, Malaysia.

https://doi.org/10.21834/ajbes.v1i3.34 


\subsection{Industrial City in Pekalongan}

Pratiwo, 2002, stated that The Groote Postweg (The Postal Road) greatly changed Java's spatial configuration, which had been formerly oriented on the axis between the kingdoms in the area and the trading towns on the north coast. Since The Postal Road enhanced the possibility of the raise of new settlements, new markets and trading places emerged. All the towns along the road were trading towns inhabited by multiethnic groups. Research by Rukayah, 2010, proved that the corridors of the Postal Road toward the center of the city have turned into commercial areas, like those in Bandung and Semarang.

The researchers aspire to unveil the potential of the road when it passes through Batik Pekalongan industrial area. Unlike other cities that produce batik-such as Yogyakarta, Surakarta, Cirebon, and Lasem-the city is located right on the road that connects all cities in Java's north coast. This research is expected to uncover other sides of batik from the perspective of urban design. Batik is very popular in Indonesia.

There are many researches discovering patterns or characteristics of certain the industrial products, but there are not many of them unveil the characteristics of an industrial city. Since there are findings about the differences in pattern between batik made in the coastal cities and the mainland cities, researchers assume that these differences may be followed by distinction in urban design. Cultures of Indonesia contribute in shaping the pattern of the products made by local industries. The question is, what about the urban design?

That question is necessary considering the fact that the existence of local industry in Pekalongan has been there since the 18th century, and that it is now growing fast and even creating its own place branding. In accordance with the statement from Beckmann \& Zenker, 2012, this research is important to be conducted. They explain about the importance of approach to new tasks for the place brand management: coordination, monitoring, and communication between the sub-brand units as key aspects of the process.

Place branding or place marketing appears mainly to promote cities as a tourist destination, or to promote cities that wish to sell their industrial products (Ham, 2008). In the world of architecture and urban design, we have known the term city landmark from Lynch, 1969. City landmark acts as a mental map for its citizens to have a better understanding of their city. For several decades, landmark has appeared in the urban design and has helped creating unique image for the city. (Eiffel tower in Paris, Sidney Opera House in Sidney, Big Ben in London, Twin Tower in Malaysia, and Merlion in Singapore, etc). In the era of the 1990s, paradigm changed, and shopping centers became the city image as the result of retail globalization (Rukayah, 2010). According to Ever, 2002, cities in various nations have a uniformed façade by showcasing malls as the landmarks. Rukayah, 2010, even discovered that the centers of traditional cities in Java have turned into commercial areas with shopping and trading buildings acting as city landmarks. From those theories, Pekalongan City (a regency located in the Central Java, $60 \mathrm{~km}$ from Semarang), well known as an industrial city and brings out unplanned phenomenon as a city with the 
branding of "Batik City". From Nurainun at all, 2008, there are 1,719 batik artisans spread across 3 subdistricts of western Pekalongan, Pekalongan East and South Pekalongan. And there are 600 batik factory and 700 garment enterprises. And has four major wholesalers that Sentono (225 stalls), Market Gamers (350 stalls) and Mega Wholesale MM (180 stalls) and Metono market. In Rio Declaration, Principle 22, it is stated that indigenous people, their communities, and other local communities have a vital role in environmental management and development because of their knowledge and traditional practices. Zoel, 2012 also stated that human resources is an important factor in the formation of local creative at Riau Province.

The background of this study is the fact that knowledge and theories about city branding have not yet uncovered the strength of people's participation while the participation actually plays a very important role. The purpose of this research is to discover the social phenomena for city branding. The target of this research is to give input to the government regarding the concept of city branding and also to complement the knowledge about the image of the city.

\subsection{Literature Review}

\subsection{The city landmark and characteristics of a particular city}

The image of a city is the first and the strongest image reflecting how people feel about the city. According to Lynch, 1969, an image requires an identity of an object or something that is different from others as well as a structure of the interconnecting pattern between the object and observers. There are five elements that create an image of a city. Among those five elements, city landmark is the one connected with this research the most such as Eiffel Tower in Paris, The Opera House in Sydney, (Ham, 2008).

Raubo, 2010, added the city's mass detail as the indicator for city branding by using Saffron City Brand Barometer. Saffron emphasized more on the detail of the cityunmistakable characteristics of a particular city that immediately make visitors feel like they are indeed in a specific city. (London double-decker buses, red telephone booths, the architectural heritage of Gaudi in Barcelona, and even the gondolas of Venice).

\subsection{Mall as a landmark}

Ever first discovered the phenomenon about building malls and changing city landscapes in the cities of Asia, Kotler and Kertajaya, 2003, stated that malls offers shopping activities, recreations, and world-class entertainment that attract all generations of citizens. New malls, with either local or foreign base, are operating side by side and become Virtual Global Village.

This paradigm appears along with the idea to market the product by using architecture as a marketing utility. Similarly, the theory of location in marketing strategy also states the 
importance of having a location in the center of the city. City central as the place of mass festivity is fitting for product marketing activities. According to Kotler et al, 1993, one of the aims for place marketing is to promote a place's values and image so that potential users are fully aware of its distinctive advantages. This paradigm strengthens the purpose of development of all countries, especially for developing countries, including those in Asia, to offer modernity in the city visual and to create lifestyle of the city dwellers.

\subsection{City branding}

Kavaratzis, 2013, stated that city Branding has gained popularity among city officials in recent years. City brands are in many ways similar to company brands. Raubo, 2010, concluded that place branding can be defined as the planning and execution of a city's existing, potential customers and other stakeholders. Dinnie, 2011, explained about the physical elements that have already existed in a city (Athens' city branding and the 2004 Olympic Games, the city branding of Barcelona, city branding through food culture, city branding through New Green Spaces, and so on). Rai, 2012, also stated that iconic buildings are tools to communicate as status symbols of the city and attract visitors.

From the discussions above, the city branding is a marketing strategy of a city. This effort starts from the physical potency of a city, and if a city doesn't have one, then the nonphysical character will be utilized to market the image. Media is used to market the cities through events, press conferences, or publicity in social media.

\subsection{The system of professional global city}

The system of professional global city discussed here is in relation with the ability of an industrial city in shaping its city branding. In Soetomo, 2009, professional town is a town that contains the process of village industrialization and is able to create showroom areas in the city central with lines of mass shops that decorate the city. Several professional cities implement the concept of city corridor as industrial and showroom areas but still manage to conserve the agrarian areas.

It was Le Corbusier that first created this concept of urban design to region design. $\mathrm{He}$ depicts the concept of urban region in a triangular diagram. The development of the particular area is a sustainable concept. Farming area is in the middle, while urban development is in the regional corridor. This model is developed within the concept of linear city development in New Urbanism, but is complemented with Transit Oriented Development in the nodes alongside the corridor. The concept of professional city is developed within the regional development framework. This concept will develop the economic activities in that particular city. The life of trading and service sectors will appear, shaping this small rural city into a professional city. Rai, 2012, also stated Townships would facilitate emergence of consolidated, economically and environmentally sustainable corridors. Integrated Townships are the way ahead to sustainable urban development. 


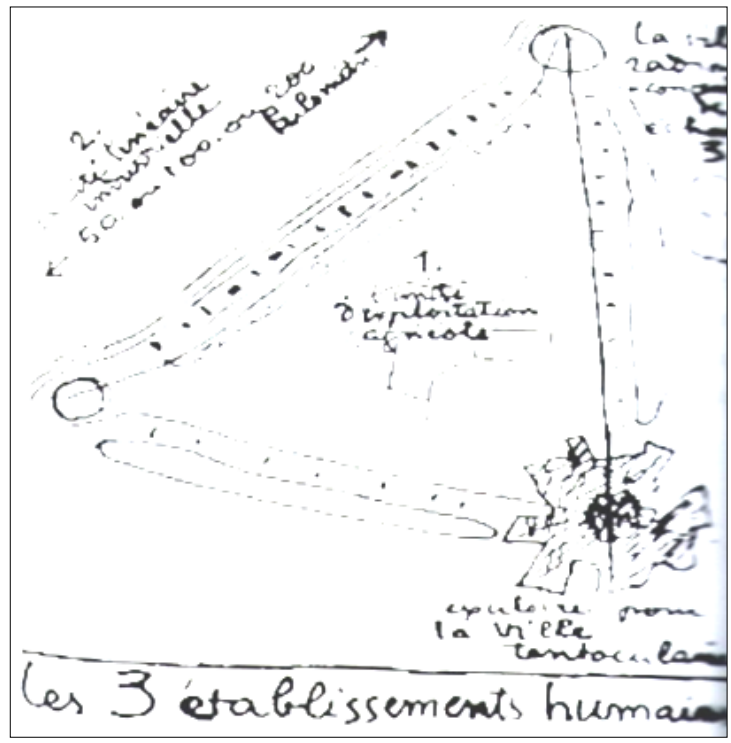

Figure 1: Human settlement from Le Corbusier

(Source: Soetomo, 2009)

\subsection{Conclusions of theory discussion}

It can be concluded that the image of the city appears because of the physical architectural aspect or the urban design aspect that becomes the characteristic of that city (during the 1970s). In the era of retail globalization in the 1990s, shopping malls become the city landmarks. Around 2000, the role of the community creates stakeholders. The capitalists along with the citizens create the image of the city. We can see this as their effort to promote the city for the purpose of investment, tourism, and creation of comfort in settlements. They explore the city potentials-both from the physical and non-physical sidesthat are the characters of the city as city branding. A theory gap appears to be observed. This gap is about a city design that naturally builds its own city branding.

\subsection{Research Method}

The data collection process is done through a series of research. Old data about Pekalongan and any information regarding the postal road are acquired through several research and journals whereas the recent data are taken within the last 10 years, where markets, shops, and malls grow very rapidly alongside the road. The lines of shops that belong to the merchants have existed since the past 10 years. 
We observe trading activities in market areas, shops, and stores along the road. Several industrial houses located on each side of the road are used as research samples. Interviews are conducted with each informant acting as the key person. Based on the theory of city branding, the informants are governments or decision makers, the citizens, the businessmen or private sectors, tourists, and investors.

This research focus only within certain aspects of urban design and intends to raise a case on how city branding naturally molded without the hands of governments. This architectural and urban design research limits the theory discussion within the aspects of landmark, shopping centers as city landmarks, and city branding. These aspects are the shift in paradigm regarding the image of a city.

\subsection{Pekalongan as a Case Study}

Industrial activities have existed since the 1800s. These activities started out from three home industry areas. They are located linearly from south to north, in the direction of the city center. There are many merchants running their businesses and created a living space with the style of jengki architecture (the work of Indonesian architects in post Dutch colonialism era) and pranggok, as work space (Wibowo, 2013).

We limit this research to not discuss the architecture uniqueness of the houses. There is a strong phenomenon about the traders build shops alongside the main road whereas rich merchants run their own industrial business in three places. These three industrial locations shape the linear track as a connector between the south and the north area toward the city (industrial corridor). Meanwhile, the display space for the traders alongside the main road that connects the city of north coast is called the shopping windows corridor.

The combination between industrial district and the display space (Setono Wholesale Market and stores area in the district of Tirto) creates The World's City of Batik as Pekalongan's city branding. The wholesale market started out from the craftsmen community that agreed to form Businessmen Coop in 1942. (Prastyani, 2005).

In 2010, the coop managed the wholesale market. With the existence of the whole sale market, this city has already had a facility to run its businesses: textile industry products, fragrant roots crafts, and also banana tree crafts business (Budiharjo, 2007). At the present day, the wholesale market is still one of biggest shopping places in Pekalongan.

The next development of central industry takes place in a settlement group of craftsmen that has functioned from generation to generation. Each house owns a display window to support the business. This adds the showroom function to the houses, along with the production and general living functions. This area is considered younger than the whole sale market, and has been officiated as Batik Village since 2007. 


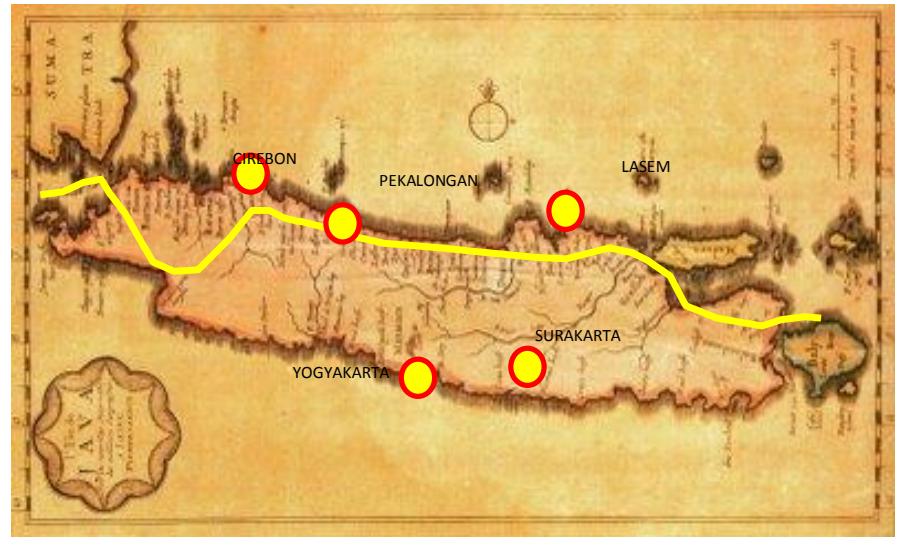

Figure 2: Postweg track that connects the cities in Java (Source: The Map of Java, 1729)

Another shopping center started to grow naturally and vastly. It is similar to the whole sale market where stores are only show rooms that function as trading facilities. The products come from the traditional craftsmen that are settled behind these store fronts. The existence of stores creates symbiosis with producers around the area.

\subsection{Findings and Discussion}

The city has developed interesting tourist attractions that were shaped from the community's local efforts since the 18th century. The efforts of the community include the forming of craftsmen coops and the initiating of the whole market. Nowadays, the market is one of the biggest trading centers located right along the main road. The craftsmen have also utilized the ex-factory as kiosks.

"...because we use the former factory building for kiosks, we don't have to pay too high for the lease. Thus we can sell quality products with cheap price..."

When it first started, the wholesale market only had 50 kiosks. Now it's developed into having 300 kiosks. The effort of the community to use this building creates a mutual symbiosis with the government. Risyanto (2008) showed that the government, the private sector, and the people have done several efforts such as rebuilding and reconstructing market place, providing facilities and marketing strategy media to improve of the city. This efforts are able to increase the number of visitors and make the market one of the main shopping tourist attractions of the city.

The location is very strategic, making it easy for visitors to stop by in the area. The display for the industrial products is located along the main road that connects the big cities of Java's north coast. This character made an urban design in this city is different from the 
other batik-producing cities in Indonesia. As the result, Pekalongan gains a unique identity that is strong enough to compete with other industrial cities. The creations of product displays along the main road are easily visible. Hence, the corridor becomes a promotional media in shaping up the city branding. The sustainability of the trading activities is well maintained because the city has industrial villages in the country side as production areas.

\subsection{Conclusion and Recommendation}

\subsection{The glory of the past}

It is possible to assume that this city has managed to shape its own image as an industrial city since long time ago. The spatial arrangement of the city suggests that there are three areas of productive industries stretched along the industrial corridor. The agglomeration of industrial productive corridor and display activities corridor gives a new insight about the system of a professional city. This city has become a professional town that contains the industrialization process of the village and creates showrooms in the city central since the 1800 s. As a professional town, the city has already had the concept of housing corridors or industrial villages as industrial areas and as showroom corridors, but still manages to conserve the farming areas. The city arrangement as the result of people's works unveils the meaning of zone-formation that classes citizens into groups of workers, rich merchants, and traders.

\subsection{Corridor as display media}

Based on the field data, the industrial activities in this city have been experiencing their own ups and downs. However, the road that passes through big cities in Java has becomes a promotional media for the city. This proves the undisputed impact of corridor on creating a strong city brand. This city doesn't need too much promotion through mass media to market its industrial products and activities. People are able to recognize the city from the vibrant activities along the corridor and from the business climate of the local citizens. Professional city system has been implemented in the city since the $18^{\text {th }}$ century. The road corridor as display media also functions as tourism area and a large shopping window. The embryonic activities of trading and service are now developing with the existence of shops and wholesale markets.

\subsection{Public participation and sustainability of the urban design in global professional cities}

The new finding in this research is the community participation that has been going on since the 1800s up to the present day. The industrial activities strengthen the inaugurations the industrial-tourism villages. The citizens of the city self-manage the tourism activities. This self-management also strengthens the city image in the process. This kind of concept 
is appropriate for new industrial cities trying to create industries that attract tourists. This is similar to the urban design idea on three human settlements. The recommendation of this research is the new knowledge about the importance of street corridors as shopping windows in industrial cities. How other countries manage to apply the urban design concept for marketing their industrial products is a question that needs to be answered through a joint research conducted by experts from developed industrial countries.

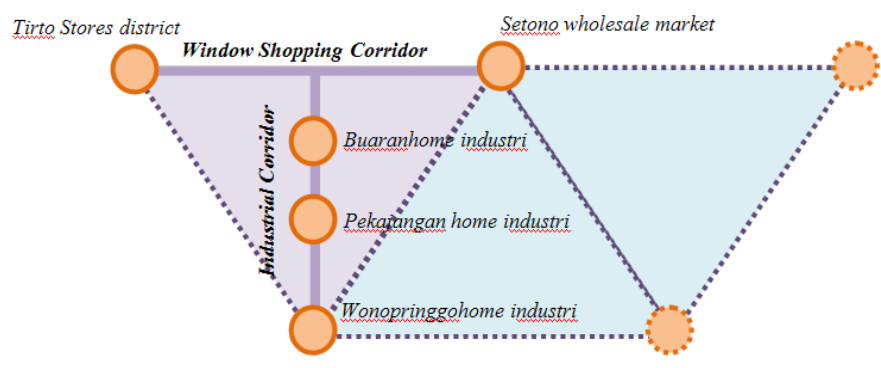

Figure 3: Toward global professional city

(Source: Researchers' analysis, 2013)

\section{Acknowledgement}

We would like to thank local industrial people that were willing to share their stories on community participation efforts in shaping tourism and industry in Pekalongan.

\section{References}

Budiharjo, A. (2007). Peningkatan kualitas penjualan produk unggulan daerah untuk penciptaan kepuasan pengunjung Pasar Grosir Pekalongan. JurnalFakultasEkonomi. Universitas Pekalongan.

Dinnie, K. (2011). City branding theory and cases: Palgravemacmillan.

Evers, H. D. \& Rudiger, K. (2002). Urbanisme di Asia Tenggara, makna dan kekuasan dalam ruang-ruang sosial. Jakarta: Yayasan Obor Indonesia.

Ham, P. V. (2008). Place branding: The state of the art. The Annals of the American Academy of Political and Social Science. Retrieved from http://ann.sagepub.com

Kotler, P. \& Kartajaya, H. (2003). (Terjemahan) Rethinking marketing suistanabde marketing centerprise di Asia. Prenticehall Inc.

Kotler, P., Haider, D. H. \& Rein, I. (1993).Places: Attracting investment, industry, and tourism to cities, states, and nations. New York: The Free Press. 
Lynch, K. (1969). The image of the city. Cambridge, Massachusetts: MIT Press.

Müge, R., Doratli, N. \& Fasli, M. (2012). City Branding and Identity. Procedia - Social and Behavioral Sciences 35(2012), 293-300. Retrieved from www.sciencedirect.com.

Nurainun, H. \& Rasyimah (2008). Analisis industri batik di Indonesia. Jurnal Fokus Ekonomi (FE). Hal, 124-135.

Prastyani, Y. G. (2005). Penentuan prioritas penyediaan sarana dan prasarana pasar batik setono sebagai objek wisata belanja di Kota Pekalongan. Tesis. Universitas Diponegoro. Semarang.

Pratiwo, P. N. (2002). Java and de groote postweg, la grande route, the great mail road, Jalan Raya Pos. In Bijdragen tot de Taal-, Land- en Volkenkunde, on the road the social impact of new roads in Southeast Asia, 158 (2002), no: 4. Leiden. 707-725.

Rai, P. T. (2012). Townships for sustainable cities. Procedia - Social and Behavioral Sciences, 37(2012), 417-426. Retrieved from www.sciencedirect.com

Raubo, A. (2010). Citybranding and its impact on city's attractiveness for external audiences. Master Thesis. Erasmus University Rotterdam.

Ristyanto, M. (2008). Potensi pasar batik setono sebagai salah satu obyek wisata di Kota Pekalongan. Program Pendidikan Diploma III Usaha Perjalanan Wisata. Fakultas Sastra dan Seni Rupa, Universitas Sebelas Maret Surakarta.

Rukayah (2010). Simbiosis di ruang terbuka Kota Simpang Lima Semarang. Disertasi Program Doktor. Universitas Diponegoro.

Soetomo, S. (2009). Urbanisasi dan morfologi, proses perkembangan peradaban dan wadah ruang fisiknya: Menuju kehidupan yang manusiawi. Graha IImu.

Suzanne, C. B. \& Sebastian, Z. (2012). Place branding: A multiple stakeholder perspective. 41st European Marketing Academy Conference, Lisbon, Portugal, 22nd - 25th May 2012.

Wibowo, A. A. (2013). Dinamika fungsi pabrik sebagai ruang produksi pada rumah pengrajin sandang di Pekalongan. Prosiding Seminar Nasional Teknopreneur hal, 68-82.

Zoel, H. (2012). The potential growth of creative industries in province of Riau. Procedia - Social and Behavioral Sciences, 65(2012), 839 - 844. Retrieved from www.sciencedirect.com 